\title{
Vjeran i iskren drug koji drži danu riječ
}

\section{Igor Duda. 2015. Danas kada postajem pionir: djetinjstvo i ideologija} jugoslavenskoga socijalizma. Zagreb i Pula: Srednja Europa i Sveučilište Jurja Dobrile. 274 str. ISBN 9789537963354

DOI: $10.21066 /$ carcl.libri.2016-05(02).0020

Knjiga Igora Dude Danas kada postajem pionir: djetinjstvo i ideologija jugoslavenskoga socijalizma, objavljena 2015. kao rezultat istraživačkoga projekta o ideologiji jugoslavenskoga socijalizma u Hrvatskoj, u historiografski fokus uzima osnivanje, djelovanje i raspad Saveza pionira Jugoslavije, odnosno njegova hrvatskoga segmenta. Duda, autor važnih povijesnih studija o jugoslavenskoj i socijalističkoj svakodnevici, u ovoj se knjizi također pozabavio svakodnevicom, no s pogledom usmjerenim na dijete. Knjiga je iscrpan historiografski pogled na političke, povijesne i vrijednosne osobitosti ideje o društvenome organiziranju djece. Premda se ideja o sveobuhvatnoj, inkluzivnoj i ideološkoj dječjoj organizaciji danas čini ne samo ideološki kompromitiranom nego i neumjesnom, ova knjiga pokazuje važnu povijesnu i društvenu posebnost toga fenomena: promatranje djeteta kao političkoga, društvenoga bića. Knjiga se dakle bavi poviješću djetinjstva u mikrosegmentu razumijevanja dječje društvenosti, odnosno djeteta u društvu, društvenoga, a ne preddruštvenoga ili izvandruštvenoga bića kakvim ga danas percipiramo.

Autor tu problematiku zahvaća u njezinu povijesnome i društvenome aspektu, prikazujući strukturu i regulaciju pionirske organizacije, kao i njezine sadržajne i ritualne kodove. Savez pionira dječja je organizacija, no njezinu strukturu, način djelovanja i ideologiju reguliraju odrasli. Dječje sudjelovanje u organizaciji nije dobrovoljno niti se $-u$ kontekstu regulacije - o toj dobrovoljnosti raspravlja. Također, bez obzira na pojam dječjega samoupravljanja koji se, u određenim razdobljima, primjenjuje na pionirsku organizaciju, dijete sudjeluje u organizaciji bez mogućnosti samoregulacije, što se odnosi na strukturu, sadržajne i ritualne aspekte pionirske organizacije. Ujedno, s obzirom na način i sadržaje djelovanja, kao i na političke procese uspostave, upravljanja i raspada organizacije, ona se jasno profilira kao dominantno performativna struktura, na što se također u knjizi ukazuje.

Pionirska organizacija začeta je još za vrijeme rata, a prve konture ocrtane su već 1941. godine. Ratne i političke okolnosti uvjetuju snažan militarizacijski impuls kojim se pristupa društvenomu organiziranju djece tijekom NOB-a. Premda se u odabiru imena i s obzirom na ideološke okvire unutar kojih se organizacija razvija može činiti da je upravo taj impuls dao ton cjelokupnoj povijesti organizacije, dokumenti koje Duda predstavlja pokazuju kako je razdoblje kasnih pedesetih godina obilježeno nastojanjima oko demilitarizacije pionirske organizacije i postupnim prenošenjem fokusa, osobito tijekom šezdesetih, ali i u sedamdesetim godinama 20. stoljeća, s organizacijskih i disciplinskih pitanja na problematiku proizvodnje i oblikovanja djetinjstva uopće. U tome kontekstu autor interpretira pojmove i diskurse koji proizvode djetinjstvo u proučavanome razdoblju, od kojih kao dominantne izdvajamo (socijalističku) ideologiju, igru, slobodno vrijeme i popularnu (dječju) kulturu, a od diskurzivne regulacije ponajprije diskurs odgovornosti odraslih za odgoj budućih naraštaja, potom diskurs ideološke ispravnosti u odgoju, diskurs nadzora i diskurs kriminalizacije izostanka kontrole odraslih nad djetetovim vremenom (najsnažnije prisutan u toposu ,odgoja ulice“ i kriminalizaciji djetetova samostalnoga upravljanja slobodnim vremenom). 
U prvome, uvodnome poglavlju autor upućeno i sažeto predstavlja osnovne konture istraživanja djetinjstva u hrvatskim humanističkim i društveno-znanstvenim okvirima, od historiografskih i etnografskih do promišljanja o društvenoj regulaciji djetinjstva, pri čemu se fokusira na razdoblje koje istražuje, spominjući istraživanja i tekstove koji se bave djetinjstvom u socijalističkoj Hrvatskoj, odnosno u Jugoslaviji. Ta je tema, kako pokazuje Duda, zanimljiva u povjesničarskome i etnografskome rakursu, pri čemu njega posebice zanima tema organiziranja djece u 20. stoljeću, koje nikako nije rezervirano samo za socijalističke ideologe. Dapače, kako navodi Duda, ideja o strukturiranome okupljanju djece i o strukturiranome dječjemu djelovanju povijesno je definirana i razvija se u okvirima istih procesa koji su iznjedrili i organiziranje odraslih od sredine 19. stoljeća: ponajprije konceptom slobodnoga vremena i iz njega proizišlim idejama o društvenoj korisnosti, ali i popularnoj kulturi. Prve dječje organizacije na tlu Hrvatske, kako Duda napominje, oslanjaju se na devetnaestostoljetnu tradiciju skautskoga, vjerskoga i političkoga udruživanja djece i mladih. O tim se udruživanjima ponešto može saznati i iz opsežnoga tematskoga priručnika Pravila društava od 1845. do 1945. koji je uredila Slavica Pleše (2000.) i u kojemu se društva dobno ne razdvajaju, no iz njega je vidljivo da su najranija udruživanja djece i mladih u Hrvatskoj povezana ponajprije s konfesionalnim organiziranjima, a potom i sa sportom. Početkom 20. stoljeća dječje su i mladenačke organizacije očitije definirane militarizacijskim impulsima, o čemu piše Iskra Iveljić u važnoj studiji o građanskome (zagrebačkome) životu i ideologijama u drugoj polovici 19. i početkom 20. stoljeća: riječ je o skautskim i sportskim društvima, rodno ekskluzivnima, čije se funkcije mogu iščitati u političkome, društvenome, socijalizacijskome i rodno uspostavnome odgojnome kontekstu. Tradiciju dječjega udruživanja Duda predstavlja izdvojenim primjerima militarističkih (nacističkih, fašističkih) dječjih europskih organizacija sredinom 20. stoljeća, kao i dokumentiranom poviješću sovjetskoga organiziranja djece pionira pri čemu se u toj organizaciji jasno artikulira ideološki mehanizam projekcije ili stvaranja kulta vladara kao oca u odnosu odrasloga i djeteta. Sličan će ideološki okvir biti prisutan i u pionirskoj organizaciji u Hrvatskoj i Jugoslaviji s fokusom na očinski lik Josipa Broza Tita.

U drugome se poglavlju predstavljaju dostupni dokumenti o uspostavi i organiziranju Saveza pionira, koji se inicijalno oslanja - barem djelomice - na međuratno iskustvo politiziranoga organiziranja djece u dječjim grupama pod zajedničkim nazivom „Budućnost“”, koje su organizirane s ciljem političkoga odgoja djece kroz zabavu, a djelovale su mahom u gradovima. Međutim, kako upozorava Duda, poslijeratni Savez pionira ne uspostavlja povijesni kontinuitet s tim grupama, nego se začetkom organizacije smatraju inicijative i procesi pokrenuti za vrijeme Narodnooslobodilačke borbe. Tako je naziv pionir, navodi autor, u upotrebi već od 1941.; od lipnja 1942. izlazi dječji list Pionir, a službeno je Savez pionira osnovan 27. prosinca 1942. na Prvome kongresu Ujedinjenoga saveza antifašističke omladine Jugoslavije u Bihaću. To službeno osnivanje, međutim, kako napominje Duda, zapravo je službena potvrda o postojanju organizacije s obzirom na to da dokumenti već i prije toga datuma spominju dječju organizaciju Saveza pionira i njezino se djelovanje na terenu već bilježi. Nadalje, Duda raspravlja o odnosu pionirske organizacije i škole te o organizacijskim rješenjima kojima se taj odnos nastoji regulirati nakon rata i tijekom cijeloga razdoblja postojanja Saveza pionira. Povijesni pogled na organizaciju uočava nekoliko bitnih povijesnih trenutaka, ponajprije ,prijelomne“ pedesete godine 20. stoljeća, 
kako ih naziva autor, u kojima se organiziranje djece u pionirskoj organizaciji, u donekle glomaznome reformskome zahvatu, snažnije usmjerava prema zabavi odnosno odgojnozabavnim postulatima, napuštajući tako militarizacijske i previše disciplinske organizacijske postavke iz prethodnoga razdoblja. Isti se reformski zahvati odnose i na organizacijske strukture i odgovornosti odraslih u odnosu prema Savezu pionira te na postupno čvršće strukturiranje i raspodjelu tih odgovornosti u suradnji sa Savezom društava „Naša djeca“. Savez pionira organiziran je dvorazinski: prva je razina dječja organizacija (Savez pionira), koja će, postupno, dobivati ponešto - barem prividne - autonomije s obzirom na protokole samoupravljanja, a na drugoj su razini odrasli uključeni u društveno reguliranu brigu o djeci (Društva „Naša djeca“, Savez društava „Naša djeca“ i partijske strukture nadzora pionirskoga saveza).

U ovome se poglavlju usmjereno pokazuje kako su pojam ,dijete“ $\mathrm{i}$ ideje o djetinjstvu u potpunosti društveno konstruirani i bitno definirani aktualnim društvenim trenutkom, pa se u povijesnome i kulturološkome smislu ne može govoriti o „univerzalnosti“ djetinjstva, nego uvijek i samo o procesima, ideologijama i manje ili više fiksiranim vrijednostima koji artikuliraju spomenute pojmove. Društvena briga o djeci u razdoblju koje istražuje ova knjiga (druga polovica 20. stoljeća) u konkretnome društvenome okružju (isprva uspostava, a potom održavanje društvenoga uređenja na ideološkim postavkama socijalizma) u bitnome je obilježena, kako jasno pokazuje Duda, određenim misaonim postulatima, od kojih kao najvažniju izdvajamo već spomenutu misao/ideju o djetetu kao društvenome biću - naspram ideje o djetetu kao preddruštvenome ili društveno isključenome, bezglasnome biću kakvu, rekli bismo, podržava aktualni društveni trenutak. Druga je važna regulatorna ideja svakako pojam odgoja koji je snažno društveno konotiran: odgoj se odnosi na dijete, ali je u nadležnosti odrasloga i usmjerava procese koji nipošto nisu dvosmjerni. Odgojni odnos, kakav iščitavamo u Dudinu predstavljanju i tumačenju dokumenata, odnos je neupitnoga autoriteta odrasloga, a uključuje i društvenu, a ne samo osobnu odgovornost odrasloga koji odgaja. U ovome se poglavlju raspravlja i o organizacijskome trokutu čija je treća strana škola, uz pionirsku dječju organizaciju i strukture odraslih uključenih u upravljanje dječje organizacije. Duda predstavlja i analizira veliki broj dokumenata i bilježi povijesne i ideološke pomake u tome kontekstu, no središnji se konceptualni okviri ne mijenjaju tijekom cijeloga razdoblja postojanja pionirske organizacije. Savez pionira cijelo vrijeme funkcionira unutar istoga okvira - u osloncu na ideje o dječjoj društvenosti i odgojnoj odgovornosti odraslih.

Taj se okvir povremeno ili u duljemu razdoblju nadopunjuje i drugim ideološkim postulatima, ponajprije socijalističkim društvenim vrijednostima, ali i spomenutim pitanjem dječje autonomije, koja je u ovome kontekstu interpretirana u idejama dječjega samoupravljanja. Nakon 1950. godine, kada se u Jugoslaviji uvodi radničko samoupravljanje, ono se, u određenoj mjeri transformirano, uvodi i na pionirskoj razini. Tijekom šezdesetih godina 20. stoljeća pionirsko se samoupravljanje razrađuje i nastoji implementirati, s više ili manje uspjeha - ovisno o razdoblju, prostoru, entuzijazmu i uključenosti odraslih i djece - u svakodnevni rad pionirskih dječjih grupa. Zanimljivo je pritom uočiti, što Duda ne propušta pokazati primjerima i iščitavanjem dokumenata, da je u dječjemu kontekstu pitanje samoupravljanja bitno kompleksnije nego u životu i radu odraslih, no isto tako i da se može uspostaviti paralelizam u odnosu odrasloga i društvene zajednice/države naspram 
odnosa djeteta i odrasloga. U oba je slučaja samoupravljanje ,izvanjsko“, a u kontekstu pionirske organizacije lijepo zrcali kompleksnost problematike odnosa autoriteta odrasloga i djeteta: pionire na „samorad“, na pokazivanje inicijative, na aktivnost, na istupanje i stvaranje potiče - odrastao, isti onaj koji će sve te procese i regulirati (i odbaciti one koje ne odobrava). Međutim, pionirsko samoupravljanje, barem u pojedinim periodima, uključuje i pionirsku samoodgovornost, u koju se ubraja i nadzor nad financijama i upravljanje njima. No proučavajući dokumente i javne diskurse, Duda zaključuje da se pionirsko samoupravljanje propituje i vrednuje u najmanju ruku ambivalentno, osobito s obzirom na rezultate. Ponegdje se spominje i da su mnoge mogućnosti u tome kontekstu ostale neiskorištene, baš kao što se i u dokumentima (zapisnicima, pravilnicima i drugim javim aktima) implicitno ili eksplicitno iščitava niz problema u organiziranju rada na terenu. Stoga se s razmjernom sigurnošću može zaključiti da su djelovanje, aktivnosti, rezultati i samoupravljanje u pionirskoj organizaciji uvijek ovisni o konkretnim osobama i okolnostima u svakoj pojedinačnoj sredini, a manje o regulatornim i preskriptivnim rješenjima.

U ovome se poglavlju otvara i još jedno izrazito zanimljivo pitanje, ono dječjega slobodnoga vremena, koje Duda predstavlja pomoću teme „ideološkoga suparništva“ pionirskoj organizaciji. Ideološkim je protivnikom pionirske organizacije, dakako, percipirana ponajprije Katolička Crkva (i u manjoj mjeri druge organizirane religijske zajednice), ali je zanimljivo da se ideološkim protivnikom percipira i popularna kultura. Taj problemski kompleks, međutim, nikako nije jednostavan, što Duda izvrsno pokazuje upućujući na mjestimično i povremeno turbulentan, pa i proturječan odnos roditelja prema pionirskoj organizaciji. Društvena uključenost i ideološki odgoj djece zahtijeva suradnju s roditeljima, koja ponegdje izostaje, posebice u razdoblju neposredno nakon rata. Ideološko suparništvo s Katoličkom Crkvom, pak, očituje se u nizu zabilježenih slučajeva u kojima svećenici, uz potporu roditelja ili bez nje, nastoje aktivnostima koje se percipiraju kao religijsko obrazovanje djeci organizirati slobodno vrijeme. U poratnome razdoblju, pa i do kraja četrdesetih godina, zabilježeni su i slučajevi gotovo izravnoga „sukoba“ u kojima se aktivnosti pionirske zajednice ciljano organiziraju i provode kako bi - vremenski ili interesno - kolidirale s obredima i aktivnostima Katoličke Crkve. No u tome nam je kontekstu zanimljivija Dudina kontekstualizacija problematike dječjega slobodnoga vremena u dvama smjerovima - u odnosu djeteta i popularne kulture i u kontekstu razumijevanja pojma djetetova „slobodnoga“ vremena. Dječje je slobodno vrijeme, kako to Duda izvrsno pokazuje, organizirano prema idejama i vrijednostima odraslih. Dapače, nestrukturirano vrijeme snažno je negativno obilježeno kao potencijalno kriminogeno - diskurs o opasnom i prijetećem „odgoju ulice“ jedan je od najperzistentnijih u kontekstu djeteta i djetinjstva, i to ne samo u istraživanome razdoblju. Popularna neparticipativna i potrošačka dječja kultura (osobito „uvozna“, zapadna) također se smatra ideološki problematičnom te se, kako pokazuje autor, djelovanje pionirske organizacije usmjerava prema nastojanjima stvaranja ideološki ,ispravne“ i dijelom participativne dječje kulture. U tome smislu važno je stvaranje zasebnoga, strukturiranoga dječjega prostora poput pionirskih domova, kutića, soba, logora i odmarališta te sadržaja kojima se ti prostori nastoje ispuniti. Duda predstavlja promišljanja o dijalektici odnosa rada i zabave, politiziranosti (ideologiziranosti) i kreativnosti djeteta, kao i gradskoga i seoskoga djeteta, te navodi brojne dokumentirane izvannastavne i izvanškolske aktivnosti u zasebnim pionirskim prostorima, koje su u velikoj 
mjeri upravljane romantiziranom idejom o pionirskome djetinjstvu koje će biti bogatije i bolje od djetinjstva generacije njihovih roditelja. Tu su uključene i prakse socijalnoga turizma, odnosno organiziranih pionirskih ljetovanja (isprva prilično politiziranih), potom cjelogodišnje kreativne ili socijalizacijske aktivnosti, ali i promišljanja o simboličkoj figuri prigodnoga sezonskoga dječjega darivatelja, koja je, kako se čini, u svim društvenim uređenjima ideološki problematizirana; tako se kao potencijalna simbolička figura darivatelja djeteta povodom Nove godine spominje i Tito, Stari Partizan ili Baba Zima, ali je ipak, kako duhovito navodi Duda, Djed Mraz uspio preživjeti jugoslavensko-sovjetski sukob koji ga je bio privremeno ideološki delegitimirao. U tome nam se kontekstu zanimljiva čini opaska koju Duda citira, a koja je navedena u zapisniku sa sastanka s književnicima „po pitanju dječje literature i pionirske štampe“ iz 1949. Djecu, sugerira nepotpisani izvor s toga sastanka, ne smijemo slikati sasvim onakvu kakva jesu nego kakvom ih želimo, što simbolički sažima povijesno i društveno mjesto prijepora i pregovaranja o djetetovoj društvenoj konstruiranosti i njegovoj društvenoj performativnosti.

U sljedećim se poglavljima pionirska organizacija tumači s obzirom na sadržajne i ritualne aspekte, koji počivaju na ideološkim konturama socijalističkoga društvenoga uređenja: preklapanje sadržajnih i ritualnih kodova najjasnije se očituje u ritualu pionirske štafete, odnosno štafeta, u kojemu je ujedinjeno sadržajno okupljanje pionirskih aktivnosti s usmjerenjem na osobu Josipa Broza Tita kao simboličkoga političkoga „oca“ pionirske organizacije i države te ritualni, manifestni karakter su-djelovanja pionirske organizacije. Pionirska se štafeta uz Štafetu mladosti „trčala“ već od prvih poratnih godina kao oblik iskazivanja poštovanja, divljenja i odane ljubavi zajedničkomu „ocu“ Titu i sadržajno je odražavala spominjane postulate o dječjoj samoaktivnosti s jedne i kultu Titove ličnosti s druge strane. Pionirsku štafetu, kao zasebnu hrvatsku republičku manifestaciju povezanu s proslavom Titova rođendana odnosno Dana mladosti u svibnju, hrvatski pioniri održavaju od 1953. godine kao, kako citira Duda, ,zbir spretno povezanih sportskih, kulturnoumjetničkih, svečanih i radnih elemenata“, a najvažnije joj je pritom obilježje naglasak na pionirskoj aktivnosti i što većoj samostalnosti - izrada štafetnih palica i pisanih poruka Titu povodom rođendana uglavnom su bili samostalni pionirski zadaci, dakako uz pomoć i „vodstvo“ uključenih odraslih. Slična je situacija bila i s drugom važnom manifestacijom, odnosno ritualom pionirske organizacije, svečanim primanjem u Savez pionira koje se, kako napominje Duda, kao obavezno i primjenjivo na sve prvoškolce u Jugoslaviji ustalilo od 1963. godine. Jesensko se svečano primanje u pionire (datumski povezano s jugoslavenskim praznikom, Danom Republike, krajem studenoga) organizira na sličan način kao i proljetna štafeta: odrasli smišljaju i odrađuju sadržaj, djeca (pioniri) to izvode i provode. Ritualni je karakter manifestacije određen trima točkama: ritualom svečanoga obećanja, ideološkim naglascima svečanosti, ali i simboličkim odjevnim kodovima - pionirskom kapom, maramom i prstenom kojim se veže marama, kao i pionirskom iskaznicom koje novi članovi Saveza pionira dobivaju prilikom svečanoga čina primanja te normiranom odjećom (gornji dio bijeli, donji plavi) namijenjenom upravo činu primanja u pionire. Ritual svečanoga obećanja, međutim, doima se još i važnijim s obzirom na snažan spoj ideološkoga i performativnoga: nove pionirke i pioniri tim se obećanjem identificiraju kao društvena bića, čak i ako toga nisu (posve) svjesni. Ujedno, svečanost i ritual, ciklus ,,pionirske godine“ kao i ,proizvodnja tradicije“ o kojoj govori Duda, danas u velikoj mjeri simboliziraju povijesnu 
sliku, pa i povijesno naslijeđe pionirske organizacije i njezinu funkciju u društvenome i političkome životu zajednice, zajedno sa spominjanom performativnošću.

Posljednje se poglavlje vrlo upućeno bavi posljednjim razdobljem djelovanja Saveza pionira, odnosno desetljećem nakon Titove smrti: Pionirska štafeta zamijenjena je donekle sličnom manifestacijom, Spomenicom rada i drugarstva, koja se održavala od 1981. Posljednji je put održana u svibnju 1990. godine, za razliku od saveznoga pionirskoga pohoda „Po Titovom rodnom kraju“ i pionirskoga logora Sutjeske, koji su posljednji puta održani u proljeće i ljeto 1989. U desetljeću nakon Titove smrti 1980. godine, usprkos nekim simboličkim inicijativama i procesima ojačavanja Saveza pionira poput, primjerice, pjesme „Pionirsko kolo“ iz 1987. autora Zdenka Runjića koju su izvodili Oliver Dragojević i pionirski zbor Zvjezdice, Savez pionira postupno gubi ne samo ideološko središte, nego i usmjerenost djelovanja. Duda izvještava o problemima financijske naravi krajem osamdesetih, koji su, dakako, odraz ideoloških i vrijednosnih prijepora. Usprkos naporima oko održavanja organizacije, jugoslavenski Savez pionira prestaje postojati činom ukidanja slovenske republičke pionirske organizacije u ožujku 1990., dok se hrvatski Savez pionira, nakon niza rasprava o depolitizaciji, odbacivanju ideologije SKJ-a i mogućemu budućemu smjeru te ili neke druge dječje organizacije, gasi u razdoblju između travnja i srpnja 1990. Generacija prvašića iz jeseni 1990. tako više nije obuhvaćena dječjom organizacijom, a sve postojeće pionirke i pioniri to jednostavno prestaju biti činom ukidanja Saveza pionira: ovakav završetak Dudine knjige sjajno ilustrira primarno performativni karakter organizacije, izvrsno nadopunjen vrlo kratkim dodatkom usmene povijesti (autoetnografije) u „Pogovoru“, u kojemu se sažimaju osobna iskustva i sjećanja autorove generacije, primljene u pionire u studenome 1983. Dominantne su figure sjećanja rituali (čin primanja, pionirski simboli, tekst svečanoga obećanja, čiji se dio citira u naslovu ovoga prikaza) koji se tumače iz perspektive bivše djece, potom promišljanje o ideologiji i inkluzivnosti organizacije te problematiziranje ideje i realizacije pionirskoga samoupravljanja.

Dudina knjiga odličan je kompendij historiografskoga promišljanja o temi djetinjstva i djeteta na mikroprimjeru dječjega organiziranja. Upućeno čitajući, predstavljajući i interpretirajući dokumente, diskurse i strategije koje uspostavljaju i oblikuju pionirsku organizaciju, Duda precizno pokazuje kako djetinjstvo biva društveno konstruirano. Pionirska organizacija ujedno se predstavlja i kao vrsta društvenoga eksperimenta s relativno nepovoljnim ishodom, ali je isto tako možemo razumjeti i kao pregovaranje s predodžbama, idejama i vrijednostima koje proizvode i oblikuju dijete unutar društvene zajednice, pri čemu ponajprije mislimo na položaj djeteta u odnosu na društvenu zajednicu. Proizvodnja „djeteta“, „socijalističkoga djeteta“ ili „djeteta“ uopće - pri čemu, dakako, mislimo na društveno operativan pojam kojime se opisuje i određuje biološko potomstvo zajednice - i njegova performativnost koje su prikazane u ovoj knjizi, predstavljaju proces pregovaranja i promišljanja odnosa „odrasloga“ i ,djeteta“, proces uspostave mehanizama razumijevanja i nadziranja potomstva, ali i održavanja predodžaba o djetetu kao biću nad kojim se ima pravo uspostaviti nadzor, čije se ponašanje smije regulirati, kojemu se trebaju impostirati vrijednosti i kojega je potrebno upućivati u razumijevanje svijeta i društva. Ključnim smo pojmom u tome kontekstu prepoznali pojam odgovornosti - odgovornosti koje biološki odrastao/odrasla ima prema biološkome potomstvu - a taj se pojam odgovornosti u ovoj 
knjizi rabi često i jasno prikazuje. Struktura pionirske organizacije temeljno počiva na ideji odgovornosti odraslih, koja pak reproducira ideje o djetetu niknule i razvijene još za romantizma - o djetetu kao budućnosti zajednice, stoga i kao društvenoj grupi vrijednoj posebne, posvećene pozornosti. Mali pomak u promišljanju toga odnosa u kontekstu pionirske organizacije vidimo u nekim mehanizmima - ne do kraja definiranima i čak, čini se, niti osobito osviještenima - prenošenja odgovornosti i davanja glasa. Dijete je u zajednici i u pogledu odrasloga, kako to argumentirano pokazuje Karìn Lesnik-Oberstein (Children's Literature: Criticism and the Fictional Child, 1994) bezglasno: ono glas dobiva samo kao bivše dijete, ponajčešće u nostalgičnome registru, rjeđe (i s umjetničkim konotacijama) u registru bijesa, no uvijek u prošlome vremenu. Pionirska organizacija usprkos svojemu dominantno performativnomu karakteru nije, dakako, bezglasnomu djetetu dala društveno neuvjetovan glas, ali je, kako to pokazuje Igor Duda, svojim djelovanjem i postulatima u određenoj mjeri - određenoj, dakako, nepropusnim ideološkim granicama - pokazala volju da o tim pitanjima promišlja.

Dubravka Zima 